\title{
GRAMMATICAL INTRICACY DALAM CERITA PENDEK KARYA PENULIS ANAK INDONESIA
}

\author{
Novia Izzati, Djatmika, Riyadi Santosa
}

\author{
littanovia25@gmail.com, \\ Universitas Sebelas Maret \\ Surakarta, Jawa Tengah, Indonesia
}

\begin{abstract}
This paper aims to describe the grammatical intricacy of short story written by an Indonesian child author. Grammatical intricacy is built of clause, nominal group, and lexis. These three aspects show us how the author expresses his mind into language. The data source is short story titled "Mahkota Surga untuk Ayah". The author is an Indonesian child whose her story has been published by Lintang. This research is a kind of descriptive qualitative using observation-notification technique (simak-catat). The data are clauses, nominal groups, and lexis of the text. The result shows that the author exploited the language in 148 clauses and most of them are complex clauses. The thing goes different for nominal groups, most of them are in simplex. Most of lexis are exploited in congruent forms. From the characteristics of the language author used this text is written in spoken language and has a high grammatical intricacy.
\end{abstract}

Keywords: grammatical intricacy, short story, clause, nominal group, lexis

\section{PENDAHULUAN}

Menulis adalah salah satu keterampilan berbahasa yang membutuhkan beberapa aspek kemampuan. Penulis harus mempunyai ide, kreativitas, imajinasi, serta dapat menyampaikannya lewat bahasa. Ekspresi verbal yang mereka tuangkan menunjukkan penguasaan bahasa dan realitas pengalaman yang dimiliki. Kemampuan mereka dalam menulis cerita pendek menunjukkan kemampuan mereka dalam merealisasikan metafungsi bahasa yaitu fungsi ideasional, interpersonal, dan tekstual.

Mendengarkan merupakan kemampuan paling sederhana dan salah satu hal yang pertama dikuasai semenjak lahir. Berbicara menjadi keterampilan bahasa kedua yang mengkombinasikan kata-kata hingga menjadi kalimat melalui oral. Lalu untuk tingkat selanjutnya ialah membaca. Sebagai keterampilan yang tingkatnya berada di atas mendengarkan dan berbicara, kemampuan membaca dapat diperoleh melalui belajar. Begitu pula dengan menulis, menulis membutuhkan ide, pengetahuan dan pengalaman tertentu sehingga lebih kompleks dibanding kemampuan yang lain.

Linguistik Sistemik Fungsional (LSF) dipilih sebagai pendekatan analisis wacana dalam penelitian ini, karena LSF dianggap mampu menganalisis wacana secara kompleks, baik itu dari aspek gramatikal maupun leksikal. Selain itu, LSF juga dapat menganalisis unit wacana secara detail, dari tingkat klausa sampai kata, baik itu teks naratif, teks percakapan maupun teks laporan, dengan berbagai macam tujuan. Pendapat ini didukung oleh penyataan Eggins (2004:2-3) bahwa LSF dianggap cukup pantas dan berguna untuk kajian teks yang berhubungan dengan pendidikan bahasa (language education), perkembangan bahasa anak (child language development), linguistik komputansi (computational linguistic), wacana media (media discourse), dan percakapan lepas (casual conversation).

Penelitian tentang wacana dengan pendekatan Linguistik Sistemik Fungsional (LSF) telah banyak dilakukan. Sebagian peneliti melakukan penelitian terhadap wacana politik, hukum, narasi, dan media 
dengan LSF untuk menunjukkan ideologi, interpersonal, maupun gaya bahasa pada teks. Hal ini menunjukkan pentingnya analisis sebuah wacana untuk memahami dan menggali lebih dalam lagi apa yang tersimpan di dalamnya dengan bukti fisik yaitu satuan lingual.

Perkembangan bahasa menjadi hal utama untuk dipelajari dari penelitian ini. Penulis cerpen ini adalah anak Indonesia. Mendeskripsikan grammatical intricacy merupakan salah satu cara agar mengetahui bagaimana perkembangan bahasa penulis sejauh ini melalui cerpen yang ia tulis. Perlu ditekankan bahwa penelitian ini tidak menilai baik dan salah, tetapi hanya mendeskripsikan bahasa yang penulis gunakan.

Menurut Rose dan Nicholls (2003:79) rentang kesempatan untuk mendapatkan bahasa ibu (aksen bahasa asli) adalah ketika anak berusia 12 atau 13 tahun ke bawah. Jadi, pada masa ini anak-anak lebih mudah menyerap pembelajaran bahasa dan kemampuan bahasa anak sudah bisa dikatakan matang karena sudah bisa membuat berbagai konstruksi kalimat. Meskipun demikian, tata bahasa mereka perlu diperhatikan untuk mengetahui kualitas bahasa Indonesia mereka.

Cerita pendek ialah salah satu bentuk literature yang menunjukkan kemampuan menulis. Cerita pendek termasuk dalam sebuah wacana. Wacana dapat dianalisis berdasarkan grammatical intricacy supaya diketahui kerumitan teksnya. Grammatical intricacy suatu teks bisa dilihat dari klausaklausa yang membentuk teks (simpleks atau kompleks) dan hubungan antar klausa untuk klausa kompleks (Soepriatmadji, 2011; Presnyakova, 2011; Ananda, 2016; Hanafiah dan Yusuf, 2016; Ma'mun, 2017).

Berdasarkan penelitian-penelitian yang sudah dilakukan di atas, grammatical intricacy dilihat dari satu aspek saja, yaitu klausa. Melihat hal ini, peneliti ingin mengetahui grammatical intricacy sebuah teks cerpen dari tiga aspek, yaitu klausa, kelompok nomina, dan leksis. Hal ini dengan alasan, bentuk klausa, baik simpleks maupun kompleks dipengaruhi oleh bentuk kelompok nomina dan leksis. Ketiga aspek ini adalah perwujudan dari grammatical intricacy. Dengan demikian dapat diketahui bagaimana kerumitan gramatika teks dari seorang penulis anak dan bagaimana dia mengeksploitasi bahasa yang sudah dipelajarinya ke dalam sebuah tulisan.

\section{METODE}

Penelitian ini merupakan penelitian kualitatif. Menurut Creswell (1998:15) penelitian kualitatif adalah "an inquiry process of understanding based on distinct methodological traditions of inquiry that explore a social or human problem".

Penelitian ini menggunakan model analisis deskriptif kualitatif yang bertujuan untuk memahami dan menggambarkan masalah yang dijabarkan dengan kata-kata. Selain itu juga untuk mengungkapkan berbagai informasi kualitatif dengan pendeskripsian yang teliti dan penuh untuk menggambarkan secara cermat sifat-sifat suatu hal, keadaan, gejala, atau fenomena-fenomena yang bisa di ungkap. Penelitian ini tidak terbatas pada pengumpulan data melainkan juga analisis dan interpretasi mengenai data tersebut (Sutopo, 2002:8).

Menurut (Sugiyono, 2013:12) penelitian kualitatif adalah penelitian yang lebih menekankan pada informasi dan data yang terkumpul berbentuk dalam kata-kata sehingga tidak menekankan pada angka. Seperti juga yang dinyatakan oleh Subroto (2013:25), disebut penelitian kualitatif karena tidak didesain berdasarkan hitungan statistik, tetapi berdasarkan model kualitatif. Datanya tidak berupa angka-angka tetapi berdasarkan tuturan atau kutipan dari tuturan, atau kata dan frasa yang terdapat dalam suatu kalimat.

Teknik pemerolehan data biasanya terkait erat dengan jenis sumber data yang digunakan. Jenis sumber data akan menentukan teknik yang akan digunakan (Santosa, 2017:53). Maka, sesuai dengan jenis sumbernya yaitu dokumen, penelitian ini menggunakan teknik simak-catat (Mahsun, 2012). Metode simak yaitu cara pemerolehan data yang dilakukan dengan menyimak penggunaan bahasa. Metode ini tidak hanya dilakukan pada data yang berbentuk lisan, tetapi juga teks tertulis. Sebagai teks tertulis, bahasa yang bersangkutan pun dalam kerangka penelitian ilmiah secara linguistis dapat dikatakan "disimak" pula jika teks itu dicermati penggunaannya (Sudaryanto, 2015:207).

Sumber data penelitian ini adalah cerita pendek berjudul "Mahkota Surga untuk Ayah" 
yang sudah diterbitkan oleh Penerbit Lintang. Penulisnya merupakan anak Indonesia usia Sekolah Dasar. Data berupa klausa, kelompok nomina, dan leksis. Data-data yang dikumpulkan tersebut dianalisis dan diinterpretasikan sehingga ditemukan grammatical intricacy teks.

\section{HASIL DAN PEMBAHASAN Struktur Teks}

Genre dalam LSF dilihat sebagai sebuah proses sosial yang bertahap dan berorientasi pada sebuah tujuan sosial (Martin, 1992:505). Setiap jenis genre teks mempunyai struktur yang berbeda. Cerpen yang merupakan akronim dari cerita pendek ini memiliki tujuan untuk menceritakan sebuah kejadian atau peristiwa (nyata ataupun fiktif) dan mempunyai sifat menghibur pembaca atau pendengar.

Cerpen "Mahkota Surga untuk Ayah" mempunyai genre naratif dengan struktur orientasi - komplikasi - evaluasi - resolusi koda (O-K-E-R-Ko). Orientasi menunjukkan pengenalan terhadap karakter dan setting cerita sebelum masuk ke inti cerita. Setelah mengetahui karakter maupun latar cerita, mulailah pada konflik yang terjadi pada tiap karakter. Ini disebut komplikasi. Komplikasi merupakan inti yang ingin diceritakan oleh penulis. Biasanya di dalam komplikasi terdapat masalah-masalah yang membutuhkan sebuah penyelesaian. Hal ini disebut resolusi.

Selain orientasi, komplikasi, dan resolusi, ada evaluasi dan koda yang membuat cerita semakin lengkap. Evaluasi merupakan cara penulis menyampaikan penilaiannya terhadap permasalahan dalam cerita. Ada banyak hal yang bisa dipelajari dari kejadiankejadian masa lampau. Introspeksi diri dan hikmah adalah bentuk dari evaluasi. Koda merupakan amanat atau pesan dari cerita yang ditujukan pada pembaca.

\section{Klausa}

Jumlah klausa yang ditemukan dalam cerpen Mahkota Surga untuk Ayah adalah 148 klausa. Semua klausa itu termasuk klausa minor, simpleks, dan kompleks yang masingmasing berjumlah 4,60 , dan 84 . Jika dibuat perbandingan, minor $:$ simpleks $:$ kompleks $=$ 1:15:21. Dari data tersebut terlihat bahwa penggunaan klausa minor di dalam teks paling sedikit, diikuti oleh klausa simpleks, dan penggunaan klausa kompleks paling banyak (minor < simpleks < kompleks).

Hasil dari klausa ini akan dihubungkan dengan penggunaan kelompok nomina (nominal group) dan leksis. Kemudian ditemukan gaya bahasa dan grammatical intricacy.

\section{Klausa Minor}

Klausa minor merupakan klausa yang tidak lengkap atau tidak mengandung verba / predikat. Klausa minor jarang digunakan dalam sebuah teks. Dalam cerpen Mahkota Surga untuk Ayah, terdapat total 148 klausa, dan hanya ada 4 klausa minor.
a. Eee... iya,
b. Iya, ya.
c. Sampai suatu hari.
d. Selamat jalan

Klausa minor tidak memiliki verba / predikat. Sulit untuk menyimpulkan mana yang berperan sebagai subjek (pelaku), predikat, dan objek (pelengkap). Klausa (a) dan (b) menggambarkan sebuah perilaku mental yang ditunjukkan secara implisit.

Klausa (c) adalah adverb of time (keterangan waktu), dan tidak mengandung setidaknya satu verba untuk menyebutnya sebagai klausa mayor. Tidak ada sebuah aktivitas yang melekat padanya.

Terkadang klausa minor merupakan bentuk elipsis, seperti data berikut:

"Siapa, sih, yang juara kelas? Kamu atau aku?"

Klausa kamu atau aku adalah elipsis dari kamu [yang juara kelas] atau aku [yang juara kelas], sesuai dengan klausa sebelumnya. Pelesapan ini dilakukan untuk mempersingkat apa yang ingin diucapkan dengan catatan lawan bicara mengerti maksud tuturan itu. Faktor konteks sangat berperan penting dalam pembicaraan ini, sehingga penutur dan lawan bicara saling memahami.

Dengan demikian, dapat disimpulkan bahwa klausa minor menunjukkan afeksi atau mengekspresikan perilaku mental tertentu dan dapat ditunjukkan lewat elipsis.

\section{Klausa Simpleks}

Ada total 61 klausa simpleks yang ditemukan dari 148 klausa. Ciri klausa simpleks adalah terdiri dari satu verba dan tanpa kehadiran konjungsi. Konstituennya 
terdiri dari subjek, predikat, pelengkap, dan adjunct. Konstruksinya variatif, diantaranya subjek - predikat - pelengkap, subjek - predikat, subjek - predikat - adjunct, dan subjek predikat - pelengkap - adjunct yang merupakan konstruksi paling lengkap.

a. Aku mengangguk.

b. Tempatnya asyik dan seru.

c. Aku selalu ingat pesan ayah.

d. Anak-anak mendengarkan dengan baik. e. Ayah memandangi wajah kami satu per satu.

f. Nurul An-Nisa' adalah tempat pembelajaran di pondok.

Tabel 1. Klausa Simpleks

\begin{tabular}{|l|l|}
\hline subjek & predikat \\
\hline $\mathrm{Aku}$ & mengangguk \\
\hline
\end{tabular}

\begin{tabular}{|l|l|}
\hline subjek & Predikat/pelengkap \\
\hline Tempatnya & asyik dan seru \\
\hline
\end{tabular}

\begin{tabular}{|l|l|l|l|}
\hline Subjek & & predikat & pelengkap \\
\hline Aku & selalu & ingat & $\begin{array}{l}\text { pesan } \\
\text { ayah }\end{array}$ \\
\hline
\end{tabular}

\begin{tabular}{|l|l|l|}
\hline Subjek & predikat & adjunct \\
\hline Anak-anak & mendengarkan & $\begin{array}{l}\text { dengan } \\
\text { baik }\end{array}$ \\
\hline
\end{tabular}

\begin{tabular}{|l|l|l|l|}
\hline S & Pred & pelengkap & adjunct \\
\hline Ayah & $\begin{array}{l}\text { mema } \\
\text { ndangi }\end{array}$ & wajah kami & $\begin{array}{l}\text { satu per } \\
\text { satu. }\end{array}$ \\
\hline $\begin{array}{l}\text { Nurul } \\
\text { An- } \\
\text { Nisa' }\end{array}$ & adalah & $\begin{array}{l}\text { tempat } \\
\text { pembelajar } \\
\text { an }\end{array}$ & $\begin{array}{l}\text { di } \\
\text { pondok }\end{array}$ \\
\hline
\end{tabular}

Subjek dan Pelengkap

Subjek dan pelengkap direalisasikan dalam bentuk yang sama, yaitu nomina dan kelompok nomina. Berdasarkan data di atas, contoh nomina yang ditemukan diantaranya $a k u$, anak-anak, dan ayah. Adapun subjek dan pelengkap yang tergolong kelompok nomina yaitu tempatnya, Nurul An-Nisa', wajah kami, pesan ayah, tempat pembelajaran.

\section{Predikat}

Predikat tidak hanya berupa verba, tetapi juga non-verba. Hal ini dapat dilihat dari klausa-klausa di atas. Predikat yang berbentuk verba berdasarkan data di atas diantaranya mengangguk, mendengarkan, ingat, memandangi. Adapun penemuan predikat yang berbentuk non-verba dua diantaranya kata adalah serta asyik dan seru.

Selain itu, ada beberapa verba yang kata dasarnya merupakan non-verba. Contoh, kata verba bernama diambil dari kata nomina/benda 'nama'. Nomina 'nama' mendapat prefik ber-, sehingga mengubahnya menjadi verba 'bernama'. Ada juga verba yang berawal dari kata sifat (adjective), seperti gembira. Kata 'gembira' mendapat prefik ber-, sehingga menjadi verba 'bergembira'. Selain itu, ada verba berlalu yang mempunyai kata dasar 'lalu'. Kata 'lalu' merupakan konjungsi waktu yang mendapat awalan ber-, sehingga mengubahnya menjadi verba.

Tabel 2. Verbalisasi
\begin{tabular}{|l|l|l|l|l|}
\hline $\begin{array}{l}\text { Prefik } \\
\text { ber- }\end{array}$ & $\begin{array}{l}\text { Kata } \\
\text { bend } \\
\text { a/no } \\
\text { mina }\end{array}$ & $\begin{array}{l}\text { Kata } \\
\text { sifat } \\
\text { (adjecti } \\
\text { ve) }\end{array}$ & $\begin{array}{l}\text { konjun } \\
\text { gsi }\end{array}$ & Verba \\
\hline Ber- & nama & - & - & $\begin{array}{l}\text { berna } \\
\text { ma }\end{array}$ \\
\hline Ber- & - & $\begin{array}{l}\text { gembi } \\
\text { ra }\end{array}$ & - & $\begin{array}{l}\text { bergem } \\
\text { bira }\end{array}$ \\
\hline Ber- & - & - & lalu & berlalu \\
\hline
\end{tabular}

Adjunct

Berdasarkan klausa di atas, yang termasuk adjunct adalah dengan baik, satu per satu, dan di pondok. Adjunct di sini direalisasikan dalam bentuk frase preposisi dan kelompok adverbial. Satuan lingual dengan baik dan satu per satu menunjukkan keterangan cara (adverb of manner), sedangkan di pondok menunjukkan keterangan tempat (adverb of place).

Selain frase preposisi dan kelompok adverbial, adjunct juga dapat direalisasikan dengan kata tunggal, seperti pada contoh berikut:

"Anak-anak kelas Khadijah tidur nyenyak."

Kata nyenyak merupakan kata tunggal yang menerangkan verba. Adjunct nyenyak menunjukkan keterangan cara. Untuk membuktikan bahwa kata tersebut masuk kategori keterangan cara ialah dengan memberi pertanyaan "bagaimana". Maka jika ditanya "bagaimana tidurnya?" jawabannya adalah "anak-anak kelas Khadijah tidur dengan nyenyak." Sedangkan untuk mengetahui apakah sebuah satuan lingual termasuk keterangan tempat dan waktu, yaitu dengan memberi pertanyaan "di mana" (keterangan tempat) dan "kapan" (keterangan waktu). 


\section{Klausa Kompleks}

Klausa kompleks ialah klausa yang memiliki konstituen lengkap dan biasanya antar klausa dipisahkan oleh konjungsi. Berdasarkan hubungan ketergantungannya, ditemukan klausa parataktik dan hipotaktik. Yang menentukan sebuah klausa masuk kategori parataktik atau hipotaktik adalah berdasarkan konjungsi atau hubungan antar klausa. Apakah kedua klausa memiliki ketergantungan satu sama lain atau bisa berdiri sendiri bahkan tanpa kehadiran konjungsi.

Parataktik

Klausa pada hubungan parataktik dilambangkan dengan angka 1, 2, dan seterusnya. Angka 1 merupakan induk klausa, sedangkan angka 2 merupakan anak klausa.

a. "Kamu sudah selesai atau nambah?"

b. Aku dan kami semua memang sangat menyayangi ayah, tapi Allah jauuuh lebih sayang.

c. Aku harus belajar dan menghafalkan AlQur'an dengan sungguh-sungguh.

d. Di Pondok Cahaya Qur'an dari kelas Khadijah sampai kelas Aminah (kelas 4-6) sibuk dengan kegiatan mengaji, sedangkan dari kelas Aisyah sampai kelas Fatimah (kelas 1-3) masih punya waktu luang lebih banyak.

Tabel 3. Klausa Kompleks - Parataktik 1

\begin{tabular}{|c|c|}
\hline 1 & +2 \\
\hline Kamu sudah selesai & atau nambah \\
\hline $\begin{array}{l}\text { Aku dan kami semua } \\
\text { memang sangat } \\
\text { menyayangi ayah, } \\
\end{array}$ & $\begin{array}{l}\text { tapi Allah jauuuh lebih } \\
\text { sayang. }\end{array}$ \\
\hline Aku harus belajar & $\begin{array}{l}\text { dan menghafalkan Al- } \\
\text { Qur'an dengan } \\
\text { sungguh-sungguh. }\end{array}$ \\
\hline $\begin{array}{l}\text { Di Pondok Cahaya } \\
\text { Qur'an dari kelas } \\
\text { Khadijah sampai kelas } \\
\text { Aminah (kelas 4-6) } \\
\text { sibuk dengan kegiatan } \\
\text { mengaji, }\end{array}$ & $\begin{array}{l}\text { sedangkan dari kelas } \\
\text { Aisyah sampai kelas } \\
\text { Fatimah (kelas 1-3) } \\
\text { masih punya waktu } \\
\text { luang lebih banyak. }\end{array}$ \\
\hline
\end{tabular}

Keempat klausa di atas merupakan klausa kompleks dengan hubungan parataktik. Konjungsi yang menjadi penghubung antar klausa yaitu atau, tapi, dan, sedangkan. Konjungsi atau menunjukkan pilihan / alternatif. Konjungsi tapi menunjukkan pertentangan/perlawanan. Konjungsi dan menunjukkan penambahan. Konjungsi sedangkan menunjukkan pertentangan.

Berdasarkan sistem logiko-semantik, contoh klausa a, b, c, d tersebut mengalami perluasan (ekspansi) ekstensi (diberi lambang +) karena anak klausa bersifat sebagai tambahan info dari induk klausa. Dengan kata lain, ekspansi ekstensi ditandai dengan konjungsi dan, atau, tetapi, sedangkan.

Klausa di atas merupakan klausa parataktik yang menggunakan konjungsi sebagai penghubung antar klausa. Pada cerpen Mahkota Surga untuk Ayah juga ditemukan bentuk lokusi, seperti berikut.

a. "Iya, Umi." jawabku.

b. "Eh, kamu, Hasna." jawab Rifa, masih dengan wajah mengantuk.

Tabel 4. Klausa Kompleks - Parataktik 2

\begin{tabular}{|l|l|}
\hline \multicolumn{1}{|c|}{ 2" } & \multicolumn{2}{|c|}{1} \\
\hline "Iya, Umi." & jawabku \\
\hline "Eh, kamu, Hasna." & $\begin{array}{l}\text { Jawab Rifa, masih } \\
\text { dengan } \\
\text { mengantuk }\end{array}$ \\
\hline
\end{tabular}

Berdasarkan sistem logiko-semantik, klausa dengan bentuk lokusi di atas mengalami proyeksi lokusi (") yang ditandai dengan tanda petik (".."). Proyeksi lokusi adalah perluasan logiko-semantik secara verbal yang berupa direct speech.

Berdasarkan kondisi di atas, dapat disimpulkan bahwa klausa parataktik ditandai dengan konjungsi tertentu (dan, atau, tetapi, sehingga, sedangkan) dan bisa berbentuk lokusi. Berdasarkan sistem logikosemantiknya, teks Mahkota Surga untuk Ayah karya penulis anak ini mengalami proyeksi lokusi (“..") dan ekspansi ekstensi (+).

Hipotaktik

Klausa pada hubungan Hipotaktik dilambangkan dengan $\alpha$ (alfa) dan $\beta$ (beta). Alfa merupakan induk klausa dan beta merupakan anak klausa.

a. Selesai makan, adzan Maghrib pun berkumandang.

b. sebelum kamu menyetorkan hafalan, ustadzah beri buku mutaba'ah. 
c. Ternyata tidak hanya aku dan Alya yang sangat senang malam itu karena besok adalah hari kunjungan keluarga.

d. Setelah selesai mengerjakan Qiyamul Lail, barulah membaca Al-Qur'an

e. Bila ada santri yang belum bisa baca huruf hijaiyyah, maka di tempat itulah dia bisa membaca.

Tabel 5. Klausa Kompleks - Hipotaktik

\begin{tabular}{|c|c|}
\hline$x \beta$ & $\alpha$ \\
\hline Selesai makan, & $\begin{array}{l}\text { adzan Maghrib pun } \\
\text { berkumandang. }\end{array}$ \\
\hline $\begin{array}{l}\text { sebelum kamu } \\
\text { menyetorkan hafalan, }\end{array}$ & $\begin{array}{l}\text { ustadzah beri buku } \\
\text { mutaba'ah. }\end{array}$ \\
\hline $\begin{array}{ll}\text { Setelah } & \text { selesai } \\
\text { mengerjakan } & \\
\text { Qiyamul Lail, } & \\
\end{array}$ & $\begin{array}{l}\text { barulah membaca Al- } \\
\text { Qur'an }\end{array}$ \\
\hline $\begin{array}{l}\text { Bila ada santri yang } \\
\text { belum bisa baca huruf } \\
\text { hijaiyyah, }\end{array}$ & $\begin{array}{lrr}\text { maka di tempat } \\
\text { itulah dia } & \text { bisa } \\
\text { membaca. } & \end{array}$ \\
\hline$\alpha$ & $x \beta$ \\
\hline $\begin{array}{l}\text { Ternyata tidak hanya } \\
\text { aku dan Alya yang } \\
\text { sangat senang malam } \\
\text { itu }\end{array}$ & $\begin{array}{l}\text { karena besok adalah } \\
\text { hari } \quad \text { kunjungan } \\
\text { keluarga. }\end{array}$ \\
\hline
\end{tabular}

Klausa hipotaktik mempunyai hubungan antar klausa yang tak dapat dipisahkan karena memiliki ketergantungan satu sama lain. Hubungan itu berupa urutan waktu, syarat, dan kausalitas. Kebanyakan klausa hipotaktik menunjukkan urutan waktu. Seperti pada kelima klausa di atas, tiga diantaranya adalah berupa urutan waktu yang ditandai dengan konjungsi selesai, sebelum, setelah (klausa nomor $\mathrm{g}$, h, j).

Selanjutnya, hubungan syarat ditandai dengan konjungsi bila... maka (klausa nomor k). Selain bila, hubungan syarat ini juga ditandai dengan konjungsi jika, kalau, apabila, karena mereka bersinonim. Terakhir, klausa hipotaktik yang menunjukkan hubungan kausalitas menggunakan konjungsi karena (klausa nomor i).

\section{Campuran (Hubungan Hipotaktik dan Parataktik)}

Dalam satu klausa kompleks tidak hanya terdapat hubungan parataktik saja atau hipotaktik saja, tetapi juga campuran keduanya. Jumlah klausa simpleks di dalam sebuah klausa kompleks ada 3 atau lebih.
Hubungan antara satu klausa dengan klausa lainnya beberapa diantaranya ada yang hipotaktik dan ada yang parataktik.

a. Aku didaftarkan saat aku naik kelas 4 SD dan adikku, Alya minta didaftarkan juga.

b. Meskipun berat karena harus menambah hafalan dan muraja'ah setiap hari, tapi aku berusaha dengan sungguh-sungguh.

c. Aku ingin menangis saat tahu Om Arman menjemput kami karena kondisi ayah semakin kritis dan kini terbaring lemah di rumah sakit.

Tabel 6. Klausa Kompleks - Campuran 1

\begin{tabular}{|l|l|l|}
\hline \multicolumn{1}{|c|}{$\boldsymbol{\alpha}$} & \multicolumn{1}{|c|}{$\mathbf{x} \boldsymbol{+}$} \\
\hline 1 & - & +2 \\
\hline $\begin{array}{l}\text { Aku } \\
\text { didaftarkan }\end{array}$ & $\begin{array}{l}\text { saat aku naik } \\
\text { kelas 4 SD }\end{array}$ & $\begin{array}{l}\text { dan adikku, } \\
\text { Alya minta } \\
\text { didaftarkan } \\
\text { juga. }\end{array}$ \\
\hline 1 & - & $\mathbf{x 2}$ \\
\hline $\begin{array}{l}\text { Meskipun } \\
\text { berat }\end{array}$ & $\begin{array}{l}\text { karena } \\
\text { harus } \\
\text { menambah } \\
\text { hafalan dan } \\
\text { muraja'ah } \\
\text { setiap hari, }\end{array}$ & $\begin{array}{l}\text { tapi aku } \\
\text { berusaha } \\
\text { dengan } \\
\text { sungguh- } \\
\text { sungguh. }\end{array}$ \\
\hline
\end{tabular}

Tabel 7. Klausa Kompleks - Campuran 2

\begin{tabular}{|c|c|c|c|c|}
\hline$\alpha$ & $\mathbf{x} \boldsymbol{\beta}$ & ' $\chi$ & $\mathbf{x}$ ? & \\
\hline & & & 1 & +2 \\
\hline $\begin{array}{l}\text { Aku } \\
\text { ingin } \\
\text { menangi } \\
\mathrm{s}\end{array}$ & $\begin{array}{l}\text { saat } \\
\text { tahu }\end{array}$ & $\begin{array}{l}\text { Om } \\
\text { Arman } \\
\text { menje } \\
\text { mput } \\
\text { kami }\end{array}$ & $\begin{array}{l}\text { karena } \\
\text { kondisi } \\
\text { ayah } \\
\text { semakir } \\
\text { kritis }\end{array}$ & $\begin{array}{l}\text { dan kini } \\
\text { terbarin } \\
\text { g lemah } \\
\text { di rumah } \\
\text { sakit }\end{array}$ \\
\hline
\end{tabular}

Klausa kompleks 1 dan m masing-masing terdiri dari 3 klausa simpleks. Dua klausa berhubungan secara hipotaktik dengan perluasan enhancement (x) dan satu klausa lagi mempunyai hubungan parataktik dengan salah satu dari keduanya. Pada klausa l, dua klausa berhubungan secara parataktik dengan perluasan ekstensi (+) karena terdapat konjungsi dan yang merupakan penambahan. Sedangkan pada klausa $m$, dua klausa berhubungan secara parataktik dengan perluasan enhancement $(\mathrm{x})$ karena terdapat konjungsi tapi. 
Selanjutnya, klausa $\mathrm{n}$ terdiri dari 5 klausa simpleks. Empat diantaranya mempunyai hubungan hipotaktik dan satu klausa lainnya berhubungan secara parataktik dengan salah satu dari keempatnya. Empat klausa yang berhubungan secara hipotaktik menunjukkan urutan waktu, mental projection, dan kausalitas jika dilihat dari konjungsinya. Mental projection ditandai dengan lambang (') dan menunjukkan perluasan ide secara kognitif. Hal ini dapat diketahui dari penggunaan verba tahu. Dua klausa simpleks pada klausa $\mathrm{n}$ memiliki hubungan parataktik dengan sistem logikosemantik: ekspansi ekstensi (+) yang menunjukkan penambahan.

Dari hasil klausa, khususnya klausa kompleks (parataktik dan hipotaktik) ditemukan konjungsi yang digunakan untuk menghubungkan beberapa klausa simpleks, diantaranya dan, atau, tetapi, sedangkan (parataktik); karena, selesai, saat, sebelum, setelah, bila, meskipun (hipotaktik).

Tabel 8. Konjungsi dan Fungsinya

\begin{tabular}{|l|l|l|}
\hline Parataktik & Konjungsi & Fungsi \\
\cline { 2 - 3 } & atau & $\begin{array}{l}\text { Penambahan } \\
\text { (additional) }\end{array}$ \\
\cline { 2 - 3 } & tetapi & $\begin{array}{l}\text { Pilihan } \\
\text { (alternatif) }\end{array}$ \\
\cline { 2 - 3 } hipotaktik & $\begin{array}{l}\text { Perlawanan } \\
\text { /pertentangan }\end{array}$ \\
\cline { 2 - 3 } & sedangkan & $\begin{array}{l}\text { Perlawanan/p } \\
\text { ertentangan }\end{array}$ \\
\cline { 2 - 3 } & bila & kausalitas \\
\cline { 2 - 3 } & meskipun & $\begin{array}{l}\text { Perlawanan/p } \\
\text { ertentangan }\end{array}$ \\
\cline { 2 - 3 } & $\begin{array}{l}\text { Saat } \\
\text { Selesai } \\
\text { Sebelum } \\
\text { Setelah/ses } \\
\text { udah }\end{array}$ & Urutan waktu \\
\hline
\end{tabular}

\section{Kelompok Nomina (Nominal Group)}

Jumlah keseluruhan kelompok nomina dalam teks cerpen Mahkota Surga untuk Ayah ialah 409. Berdasarkan unsur pembentuk makna, kelompok nomina dibagi menjadi 2 yaitu simpleks dan kompleks. Kelompok nomina simpleks digunakan sebanyak 396 dan kompleks sebanyak 12. Penggunaan bentuk simpleks lebih banyak dibanding bentuk kompleks.
Berdasarkan unsur pembentuknya, terdapat istilah thing (T), deictic (D), classifier $(\mathrm{C})$, epithet (E), qualifier (Q), dan numeral (Num). Di dalam bahasa Inggris terdapat istilah head, pre-modifier dan post-modifier. Premodifier mengacu pada unsur deictic, numeral, epithet, dan classifier dimana letaknya berada di sebelah kiri thing, sedangkan post-modifier mengacu pada qualifier yang terletak di sebelah kanan thing. Thing di sini berperan sebagai head.

a. karena aku bercita-cita ingin jadi seorang penghafal Al-Qur'an.

b. Alhamdulillah, aku sudah punya kenalan beberapa teman.

c. Yang belum ustadzah panggil bisa saling simak dengan temannya.

d. "A ... anak-anakku, maafkan semua kesalahan ayah selama ini.

Tabel 9. Kelompok Nomina

\begin{tabular}{|c|c|c|c|c|}
\hline \multicolumn{2}{|l|}{ Seorang } & \multicolumn{2}{|c|}{ penghafal } & Al-Qur'an \\
\hline \multicolumn{2}{|l|}{$\mathrm{D}$} & \multicolumn{2}{|c|}{$\mathrm{T}$} & $\mathrm{C}$ \\
\hline \multicolumn{2}{|l|}{ kenalan } & \multicolumn{2}{|c|}{ beberapa } & teman \\
\hline \multicolumn{2}{|l|}{$\mathrm{T}$} & \multicolumn{2}{|l|}{ num } & $\mathrm{C}$ \\
\hline \multicolumn{5}{|c|}{ Yang belum ustadzah panggil } \\
\hline \multicolumn{5}{|c|}{$\mathrm{T}$} \\
\hline semua & & alahan & ayah & selama ini \\
\hline num & $\mathrm{T}$ & & $\mathrm{D}$ & Q \\
\hline
\end{tabular}

Keempat kelompok nomina di atas tiga diantaranya (o, p, q) berbentuk simpleks dan sisanya (r) berbentuk kompleks. Contoh $r$ termasuk kompleks karena mengandung qualifier dan salah satu dari num, deictic, classifier, dan epithet. Contoh o, p, q termasuk simpleks karena tidak mengandung qualifier.

Berbeda dengan bahasa Inggris, kelompok nomina dalam bahasa Indonesia pre-modifier dan post-modifiernya tidak tentu. Seperti contoh di atas, numeral bisa berperan sebagai premodifier yang terletak sebelum thing dan post-modifier yang terletak sesudah thing. Begitu pula dengan deictic, bisa berperan sebagai premodifier dan post-modifier.

Teks didominasi oleh kelompok nomina simpleks yang mana mempermudah pembaca anak dalam memahami isi bacaan. Susunannya juga baik dan tidak membingungkan. 


\section{Leksis}

Dalam teks cerpen Mahkota Surga untuk Ayah ditemukan leksis sebanyak 760 dengan jenis kongruen dan ingkongruen. Leksis yang paling banyak ditemukan di dalam teks ialah leksis kongruen.

e. Sore itu, jadwal anak-anak pondok adalah membersihkan kamar masing-masing.

f. Kak Rasyid mendapatkan beasiswa

g. Saat pembagian kelas, aku masuk kelas Khadijah A,

h. nanti disiram mukanya sama ustadzah, lho!

Tabel 10. Kongruensi dan Inkongruensi

\begin{tabular}{|l|l|l|l|}
\hline Kata & $\begin{array}{l}\text { Realitas } \\
\text { Fisik }\end{array}$ & $\begin{array}{l}\text { Realitas } \\
\text { Simbol } \\
\text { (dalam } \\
\text { Klausa) }\end{array}$ & \\
\hline $\begin{array}{l}\text { members } \\
\text { hkan }\end{array}$ & aktivitas & nomina & $\begin{array}{l}\text { nominali } \\
\text { sasi }\end{array}$ \\
\hline beasiswa & $\begin{array}{l}\text { Biaya } \\
\text { pendidikan } \\
\text { yang } \\
\text { diberikan } \\
\text { kepada } \\
\text { seseorang }\end{array}$ & nomina & $\begin{array}{l}\text { Nominalis } \\
\text { asi/tekni } \\
\text { kalisasi }\end{array}$ \\
\hline masuk & aktivitas & verba & kongruen \\
\hline muka & benda & nomina & kongruen \\
\hline
\end{tabular}

Kata membersihkan pada klausa $\mathrm{s}$ merupakan leksis inkongruen, begitu pula dengan kata beasiswa pada klausa t. Mengapa inkongruen? Jika dilihat dari konstituennya, membersihkan kamar masing-masing merupakan pelengkap dan masuk kategori kelompok nomina. Kata membersihkan yang masuk sebagai salah satu satuan lingual pada kelompok nomina tersebut mempunyai bentuk nomina. Pada dasarnya, kata "membersihkan" atau "bersih" menunjukkan sebuah aktivitas yang direalisasikan dengan verba. Dalam kalimat tersebut membersihkan mengalami nominalisasi, maka menunjukkan inkongruensi.

Selanjutnya, kata beasiswa ialah istilah teknis yang mengacu pada sebuah bantuan biaya pendidikan yang diberikan kepada seseorang. Untuk mengetahui istilah beasiswa membutuhkan pengetahuan tertentu. Jadi, tidak semua anak memahami istilah ini.

Untuk kata masuk dan muka, keduanya adalah kongruen. Alasannya, kedua leksis ini disimbolkan secara langsung. 'Masuk' merupakan sebuah aktivitas fisik yang direalisasikan dengan verba, dan pada klausa tersebut 'masuk' juga berbentuk verba. Lalu, 'muka' atau kata lain dari wajah merupakan benda dan direalisasikan dengan nomina. Dalam klausa tersebut 'muka' juga direalisasikan dengan nomina.

Teks menggunakan beberapa kosakata berbahasa Arab seperti muraja'ah, ustadzah, umi, hafidzah, qiyamul lail dan murottal. Hal ini disebabkan faktor lingkungan yang melingkupi penulis anak. Tidak semua orang mengetahui istilah Arab, khususnya bagi orang yang memiliki lingkungan berbeda dengan penulis.

Karena teks lebih banyak didominasi oleh leksis kongruen dibanding inkongruen dan hanya mengandung beberapa istilah Arab, anak-anak tidak terlalu sulit memahami isi cerita jika dilihat dari sisi pembaca. Teks cerpen tidak banyak mengandung kosakata sulit, teknikalisasi maupun abstraksi. Jadi keterbacaannya cukup tinggi.

\section{KESIMPULAN}

Berdasarkan hasil penelitian, dapat disimpulkan bahwa pada teks cerita pendek Mahkota Surga untuk Ayah ditemukan beberapa fakta sebagai berikut:

1. Leksis yang paling banyak dipakai oleh penulis anak ialah leksis kongruen dibanding inkongruen.

2. Penggunaan kelompok nomina didominasi oleh bentuk simpleks.

3. Teks banyak mengandung klausa kompleks. Jumlahnya melebihi klausa simpleks.

Dari ketiga fakta di atas terdapat hubungan antara satu dengan yang lain. Pertama, leksis dan kelompok nomina memiliki keterikatan. Penggunaan leksis kongruen yang lebih dominan di dalam teks mempengaruhi penggunaan kelompok nomina yang mana bentuk simpleks akan mendominasi. Kedua, hubungan leksis dan klausa. Pemakaian leksis kongruen yang lebih dominan juga mempengaruhi bentuk klausa menjadi lebih dominan kompleks. Ketiga, hubungan kelompok nomina dengan klausa. Pemakaian kelompok nomina simpleks di dalam teks mempengaruhi bentuk klausa menjadi lebih kompleks.

Diketahui bahwa cerpen Mahkota Surga untuk Ayah merupakan karya penulis anak dan target pembacanya juga anak-anak. 
Penggunaan leksis kongruen dan kelompok nomina simpleks mempermudah anak-anak dalam memahami isi cerita. Kosakatanya tidak banyak yang sulit dan sering digunakan dalam kehidupan sehari-hari.

Untuk klausa dimana penggunaannya didominasi oleh klausa kompleks menyebabkan terlalu banyaknya pemakaian kata tugas (function words). Kondisi ini membuat kompleksnya ide yang ingin disampaikan. Meskipun demikian, pembaca anak menjadi lebih mudah memahami teks dengan pertimbangan pemakaian kosakata yang lebih sederhana. Melihat hal di atas, maka dapat disimpulkan bahwa teks cenderung ke bahasa lisan dan memiliki kerumitan gramatika yang cukup tinggi.

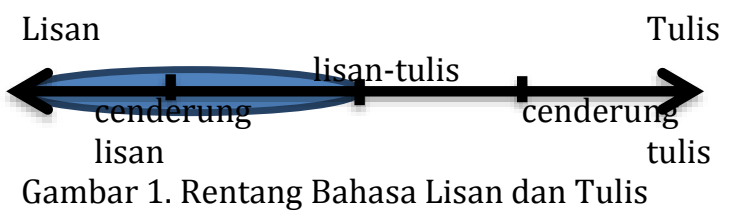

Teks cerpen ditulis dengan cara naratif dengan struktur orientasi - komplikasi - evaluasi - resolusi - koda dan disampaikan dengan bahasa lisan. Cara penulisan seperti ini sangat baik bagi perkembangan bahasa dan moral anak, karena di dalam teks naratif tidak hanya menceritakan kronologi kejadian, tetapi juga diikuti evaluasi dan koda. Seperti yang telah disampaikan Djatmika (2012) dan Djatmika \& Wibowo (2016), buku cerita bisa menjadi sarana pendamping bagi proses perkembangan bahasa anak karena memiliki dua peran penting, yaitu sebagai model olah bahasa yang efektif dan sarana untuk merealisasikan keterampilan bahasa.

Diharapkan penelitian ini bermanfaat secara praktis bagi pemerolehan dan perkembangan bahasa anak. Selain itu, penelitian ini juga diharapkan bermanfaat secara teoritis seperti, bagaimana menyusun sebuah klausa kompleks dan kelompok nomina, serta memilih kosakata yang sesuai. Bagi bidang Linguistik Sistemik Fungsional, diharapkan mampu memperkaya khazanah teori dan untuk acuan penelitian selanjutnya.

\section{DAFTAR PUSTAKA}

Alfirdausi, Fathiyah Amatullah, dkk. (2016). Penulis Cilik Indonesia: Mahkota Surga untuk Ayah. Surakarta: Lintang.

Ananda, Rizky. (2016). Grammatical Intricacy and Lexical Density of Reading Texts of English Textbook for Senior High School Students Tesis. Universitas Negeri Medan.

Creswell, John W. (1998). Qualitative Inquiry and Research Design: Choosing among five traditions. Thousand Oaks: SAGE Publications.

Djatmika. (2012). Kualitas Olah Bahasa Anak Usia Sekolah Dasar dalam Kegiatan Bercerita: Sebuah Proses Pemerolehan Bahasa Anak. Metalingua Jurnal Penelitian Bahasa, Vol.10, No.2.

Djatmika \& Wibowo, Agus Hari. (2016). Indonesian Language Quality of Stories Written by Indonesian Children Authors. dalam International Seminar Prasasti III: Current Research in Linguistics. Surakarta, Indonesia: Program Pascasarjana, Universitas Sebelas Maret.

Eggins, S. (2004). An Introduction to Systemic Functional Linguistics. London: Continuum.

Hanafiah, Ridwan \& Yusuf, Muhammad. (2016). Lexical Density and Grammatical Intricacy in Linguistic Thesis abstract: A Qualitative Content Analysis. Dalam Seminar 1st English Education International Conference (EEIC) in conjunction with the 2nd Reciprocal Graduate Research Symposium (RGRS) of the Consortium of Asia-Pacific Education Universities (CAPEU) between Sultan Idris Education University and Syiah Kuala University. Banda Aceh, Indonesia: Jurusan Pendidikan Bahasa Inggris, Universitas Syiah Kuala. 
Mahsun. (2012). Metode Penelitian Bahasa: Tahapan Strategi, Metode, dan Tekniknya. Jakarta: PT RajaGrafindo Persada.

Ma'mun, Nadiah. (2017). Grammatical Intricacy on Students' Writing. Vision: Journal for Language and Foreign Language Learning, Vol.6 No.1. 89-98.

Presnyakova, Irina. (2011). Systemic Functional Analysis of Elementary School Language Arts Textbooks. Tesis. Marshall University.

Rose, Colin \& Nicholl, Malcolm J. (2003). Accelerated Learning, Cara Belajar Cepat Abad XXI. Penerjemah Dedy Ahimsa. Bandung: Penerbit Nuansa.

Santosa, Riyadi. (2017). Metode Penelitian Kualitatif Kebahasaan. Surakarta: UNS Press.

Soepriatmadji, Liliek. (2011). Lexical Density dan Grammatical Intricacy Materi Bacaan pada Buku Bahasa Inggris Kelas 6 SD. Dinamika Bahasa dan Ilmu Budaya, Vol. 5, No. 2. 45-54.

Subroto, E. (2013). Pemerian Morfologi Bahasa Indonesia. Yogyakarta: Media Perkasa.

Sudaryanto. (2015). Metode dan Aneka Teknik Analisis Bahasa. Yogayakarta: Sanata Dharma University Press.

Sugiyono. (2013). Metode Penelitian Kuantitatif, Kualitatif, dan R\&D. Bandung: CV Alfabeta. 